\title{
Vashegyite from Gaura cu Muscă Cave (Locvei Mountains, Romania): a new and rare phosphate occurrence
}

\author{
Bogdan P. Onac ${ }^{1}$, Luminița Zaharia ${ }^{2}$, Joe Kearns ${ }^{3}$, Daniel Veres ${ }^{4}$

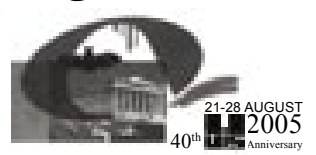 \\ Paper presented during the 14th International Congress of Speleology, Kalamos (Greece) 21-28 August 2005.
}

\author{
Abstract: \\ Onac B. P., Zaharia L., Kearns J., Veres D. 2006. Vashegyite from Gaura cu Muscă Cave. \\ International Journal of Speleology, 35 (2), 67-73. Bologna (Italy). ISSN 0392-6672.
}

This study investigated the occurrence of vashegyite from a guano-rich deposit located in the Gaura cu Muscă Cave, Romania. Analytical methods used include optical microscopy, X-ray powder diffraction (XRD), scanning electron-microscopy (SEM), inductively coupled plasma-atomic emission spectrometry (ICP-AES), thermal investigations and Fourier-transform infrared (FT-IR) analyses. Vashegyite occurs as friable, chalky white, irregular nodules of up to $2.5 \mathrm{~cm}$ in diameter, within a $15 \mathrm{~cm}$ thick sequence of organic and minerogenic sediments. The chemical structural formula is: $\left(\mathrm{Al}_{10.91} \mathrm{Fe}^{3+}{ }_{0.06} \mathrm{Na}_{0.1} \mathrm{Ca}_{0.02} \mathrm{Mg}_{0.08}\right)_{\Sigma=11.17}\left[\left(\mathrm{PO}_{4}\right)_{8.78}\left(\mathrm{SiO}_{4}\right)_{0.056}\right]_{\Sigma=8.83}(\mathrm{OH})_{6.17} \cdot 43.79 \mathrm{H}_{2} \mathrm{O}$. Electron microscope images show vashegyite crystals to be flattened on (001). The orthorhombic lattice constants of vashegyite determined by XRD are $a=10.766(2) \AA, b=15.00(4) \AA, c=22.661(1) \AA$, and $V=3660.62 \AA^{3}(Z=4)$. The major weight loss, reflected in 3 endothermic peaks, was observed between $40^{\circ}$ and $200^{\circ} \mathrm{C}$, corresponding to the removal of water molecules. Vashegyite FT-IR absorption bands are comparable in position and relative intensity to other Al-phosphates.

Water percolating through guano becomes strongly acidic and reacts with the clay-rich sediment laid down by the underground stream to form vashegyite. In the lower part of the investigated profile, crandallite and ardealite were also found.

Keywords: vashegyite, phosphate, guano, cave minerals, Romania

Received 1 April 2006; Revised 9 May 2006; Accepted 10 May 2006

\section{INTRODUCTION}

Vashegyite(theoretical formula: $\left.\mathrm{Al}_{11}\left(\mathrm{PO}_{4}\right)_{9}(\mathrm{OH})_{6} \cdot 38 \mathrm{H}_{2} \mathrm{O}\right)$ was reported for the first time in nature from the oxidation zone of the siderite-ankerite deposit from Vashegy (currently known as Zeleznik in Slovakia) (Zimanyi, 1909). A few years later, it was discovered in altered slates at Gem Mine (Manhattan, Nevada) (Clinton, 1929). Later, vashegyite was documented from a variety of non-cave environments in Austria,

1) Dept. of Geology, University of South Florida, 4202 E. Fowler Ave., Tampa, FL 33620, USA; Dept. of Mineralogy, "Babes-Bolyai" University \& "Emil Racoviță" Institute of Speleology, Clinicilor 5, 400006 Cluj, Romania (bonac@cas.usf.edu)

2) Dept. of Mineralogy, "Babes-Bolyai" University, Kogalniceanu 1, 400084 Cluj, Romania

(lzaharia@bioge.ubbcluj.ro)

3) Materials Research Institute, The Pennsylvania State University, University Park, PA 16802, USA (jkearns@psu.edu)

4) Dept. of Physical Geography and Quaternary Geology, Stockholm University, Svante Arrhenius 8C, SE-106 91 Stockholm, Sweden \& „Emil Racoviță” Institute of Speleology, Clinicilor 5, 400006 Cluj, Romania (daniel.veres@natgeo.su.se)
Belgium, Brazil, the Czech Republic, Germany, Hungary, Italy, Slovakia, the U.S.A., and Antarctica (Bannister \& Hutchinson, 1947; Hausen, 1962; Frondel et al., 1968; Milton et al., 1982; van Tassel, 1985; Barczuk \& Tatur, 2003; Atencio et al., 2005). Over the last 20 years, there have also been a number of studies that identified vashegyite in various cave environments from Albania, Australia, Germany, Japan, and the U.S.A. In most cases, vashegyite forms as a result of reactions between bat or bird guano (source of phosphorus) and floor clay or volcanic rocks (source of aluminium) (Kizaki, 1983; Kashima, 1988, 1993; Vennum et al., 1994; Rüger et al., 1995; Hill \& Forti, 1997; Forti et al., 2000).

The first detailed investigation of vashegyite from the type locality was undertaken by Koch \& Sarudi (1963). SEM and chemical analyses were performed on the sample, but these authors failed to recognize the crystallinity of the material, suggesting instead that the mineral was amorphous. The XRD studies carried out by McConnell (1974) concluded that vashegyite belongs to the group of sheet phosphates. He successfully indexed the powder patterns assuming vashegyite and kaolinite have analogous structures. The most thorough examination of vashegyite was 
completed by Johan et al. (1983). They were able to make use of both single-crystal and powder diffraction techniques to obtain the unit-cell dimensions, which they found to vary with water content. The physical properties, chemical analyses, SEM, thermal and infrared investigations added supplementary information that allowed Johan et al. (1983) to better characterize vashegyite.

The goal of this paper is to document vashegyite from a new occurrence and to establish the physical and chemical factors controlling its deposition. This is the only reported occurrence of vashegyite in Romania and, to our knowledge, the second in a European cave.

\section{LOCATION AND OCCURRENCE}

Gaura cu Muscă Cave is located in the southern most part of the Locvei Mountains, in the left slope of the Danube Gorge, about $12 \mathrm{~km}$ downstream of the city of Moldova Nouă (Fig. 1a). The existence of the cave has been known for a long time as its entrance facing the Danube (Fig. 1d) was fortified until early 1800 .
The phosphate material obtained from Gaura cu Muscă Cave consists of dull (chalky) white irregular nodules up to $2.5 \mathrm{~cm}$ across. All samples are friable and usually covered by a millimeter-size sandy clay film (Fig. 1c). They were collected from a $15 \mathrm{~cm}$ thick sequence of organic and mineral sediments accumulated on the floor of the Bats Room (Fig. 1, black dot). The studied profile is located in the southern side of the above mentioned room and exhibits four main layers (Fig. 1b). The upper $4 \mathrm{~cm}$ of this sequence (layer 1) consists of fresh guano. Measured $\mathrm{pH}$ value of the water extracted from this organic layer was 5.2; $\mathrm{pH}$ values of 5 and 6 were earlier reported by Negrea $\&$ Negrea (1979). The second layer (2) corresponds to a highly phosphatized, light brown to ochre silty clay approximately $2 \mathrm{~mm}$ thick. The third layer (3) is a dark brown, organic-rich clay approximately $3 \mathrm{~cm}$ thick. The phosphatic material investigated is scattered throughout the whole upper part of the third layer (Fig. 1b). The transition between layers 2 and 3 is gradual and their internal organization alike. Directly overlying the limestone bedrock (layer 5) there is a layer (4) of fossil guano of which the thickness varies between 1 and $1.5 \mathrm{~cm}$. Crandallite and ardealite were

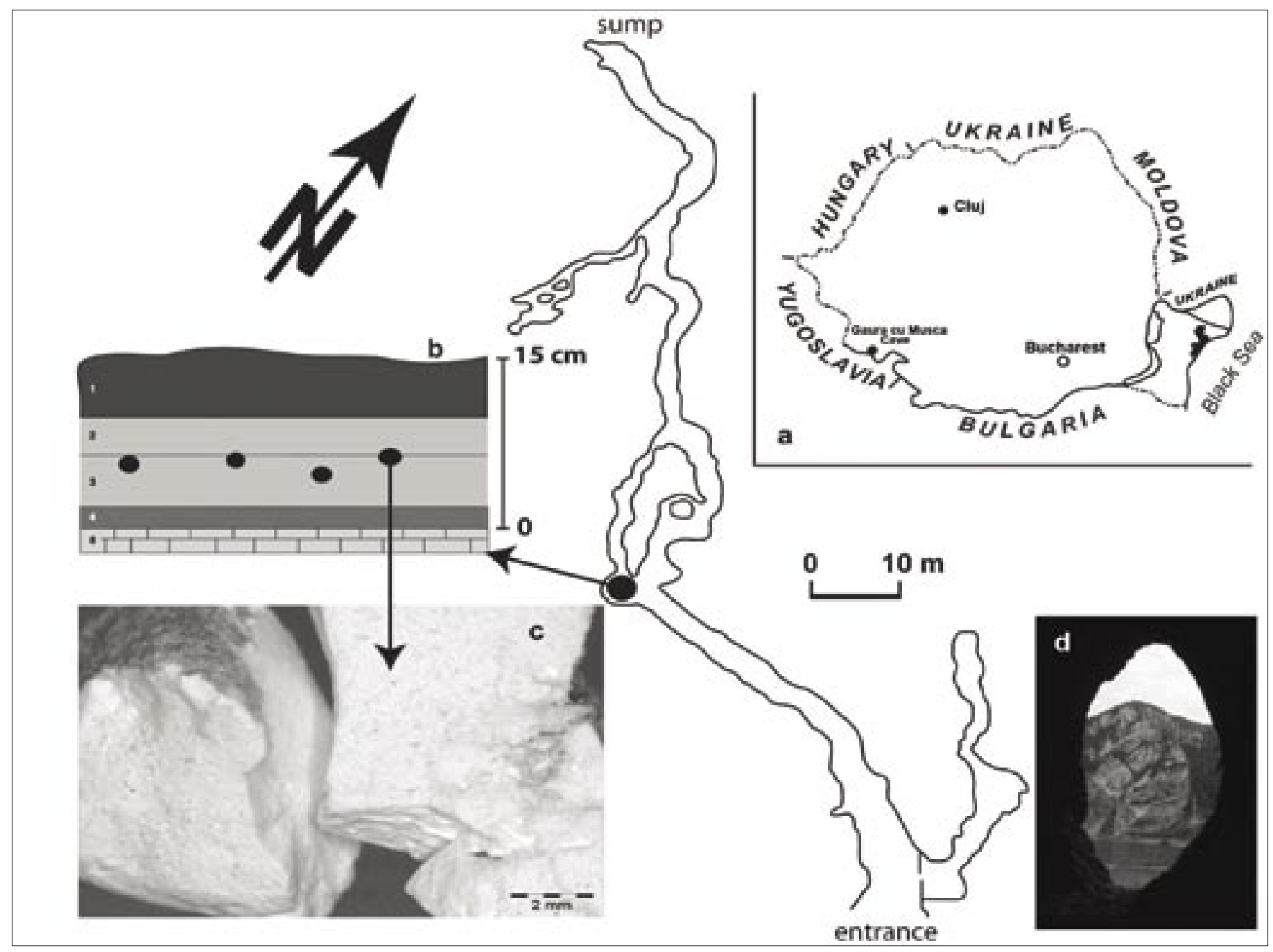

Fig. 1. Map of the Gaura cu Muscă Cave; (a) location within Romania; (b) profile through the guano deposits (black dots indicate vashegyite nodules); (c) photo of a vashegyite aggregate; (d) the cave entrance facing the Danube River. 
identified within this horizon. A brown, thin (submillimetre) skin of carbonate hydroxylapatite overlies the limestone. Layer boundaries within this profile are clearly seen as their colours vary significantly.

Only a few months after we first sampled the cave, we found the original profile slightly altered by the cave stream. The upper two layers were partly removed and some more silt and clay was added over the third horizon during a flooding event. In some parts of the room, however, the sediment sequence remained intact.

\section{ANALYTICAL RESULTS}

\section{Morphology and physical properties}

Under SEM, vashegyite most commonly occurs as micrometric prismatic crystals arranged in the shape of sheafs. The crystals are flattened on (001); the forms recognized are $\{001\},\{010\}$, and $\{110\}$ (Fig. 2a-d). The habit can be described as tabular. The dimensions of a single plate ranges between 3 and $15 \mu \mathrm{m}$. SEM photomicrographs (Figs. 2a, b), taken at two different magnifications, show the typical arrangements of the crystals. The mineral is dull white, with an earthy lustre and a white streak. The Mohs hardness is estimated to be between 1.5 and 2.5 , the cleavage is along the crystal's elongation, the tenacity is weak, and the fracture is uneven.

\section{$X$-ray and thermoanalytical data}

Crystals of vashegyite were too small for single crystal investigation. The unit cell data were necessarily computed from X-ray powder diffraction data, recorded with a Philips X'pert MPD diffractometer using $\mathrm{Cu}-\mathrm{K}_{\alpha}$ radiation generated at 40 $\mathrm{kV}$ and $30 \mathrm{~mA}$. The instrument was calibrated using NBS $640 b$ silica standard. Diffraction patterns were recorded from $2^{\circ}$ to $72^{\circ} 2 \theta$ in step scan mode using a $0.01^{\circ}$ step size and a counting time of $3 \mathrm{~s} / \mathrm{step}$. A receiving slit of $0.2 \mathrm{~mm}$ was used. Peak positions were determined by fitting the numerical profiles with a Pearson VII function. The quality of the diffraction spectrum was rather poor (Fig. 3) given the nature of the mineral (rapid dehydration, deformation of cleavage planes, etc.). However, the orthorhombic unit-cell parameters of vashegyite, refined from 22
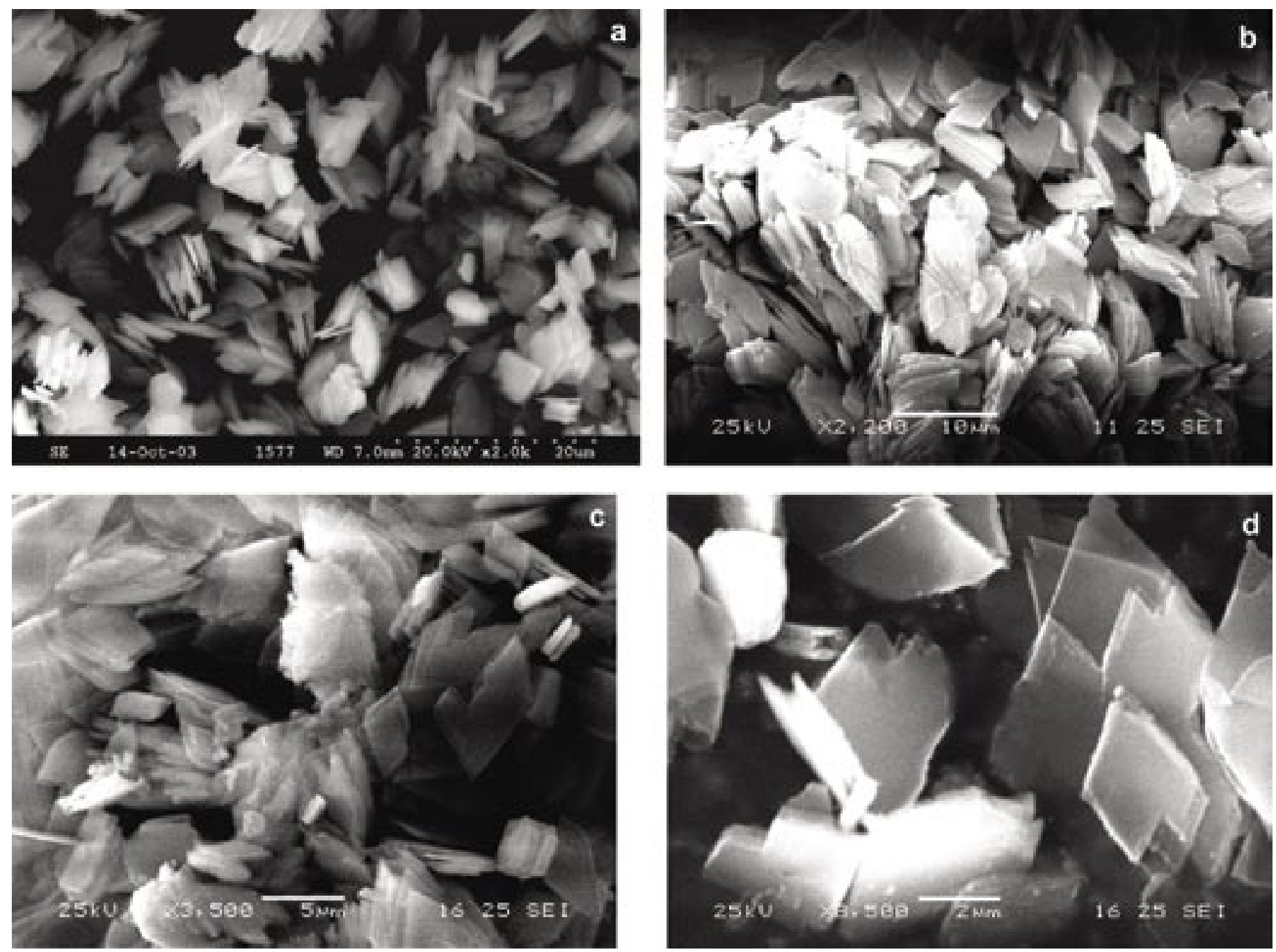

Fig. 2. Scanning electron microphotographs of vashegyite crystals from Gaura cu Muscă Cave. 


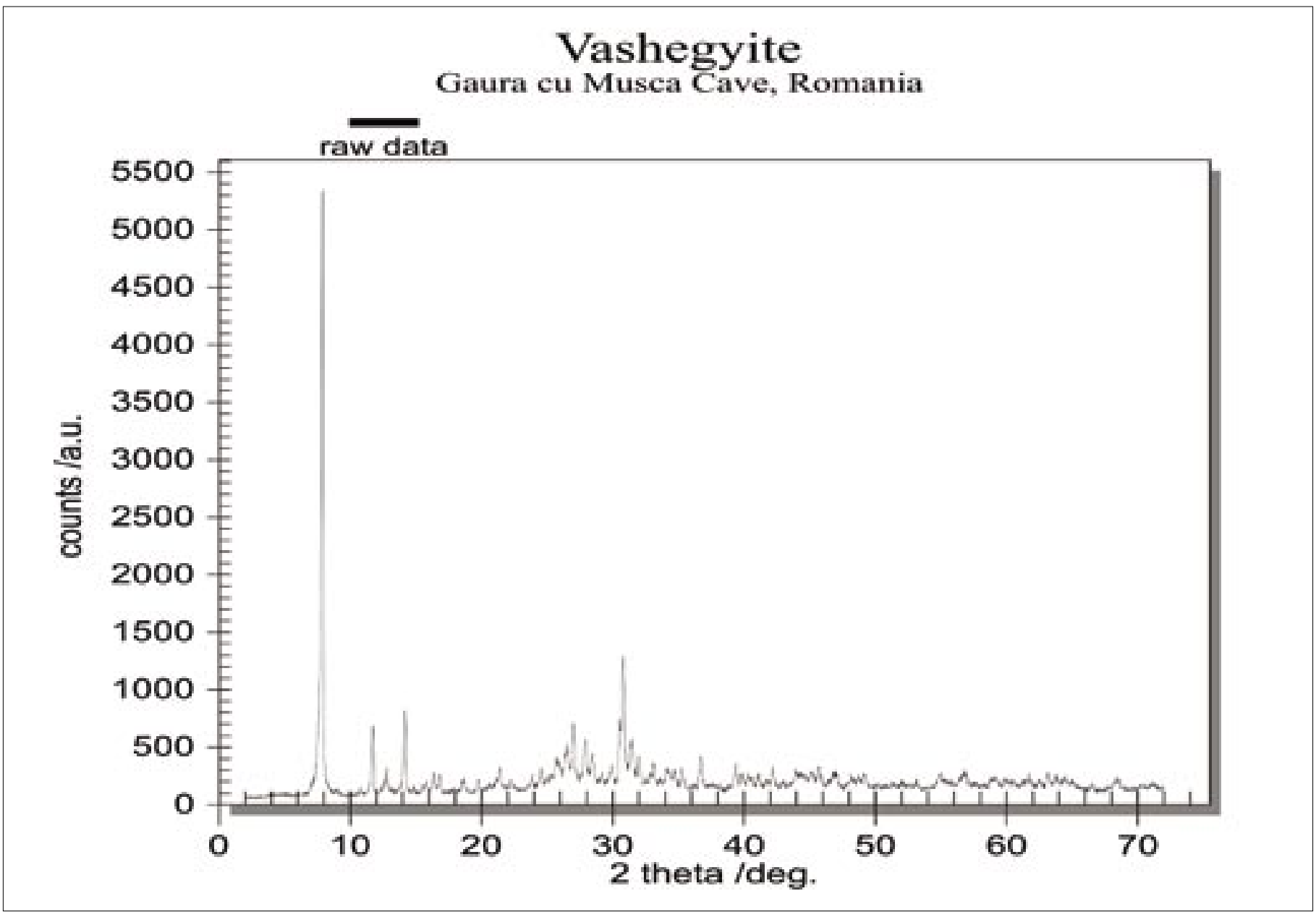

Fig. 3. The diffraction pattern of vashegyite.

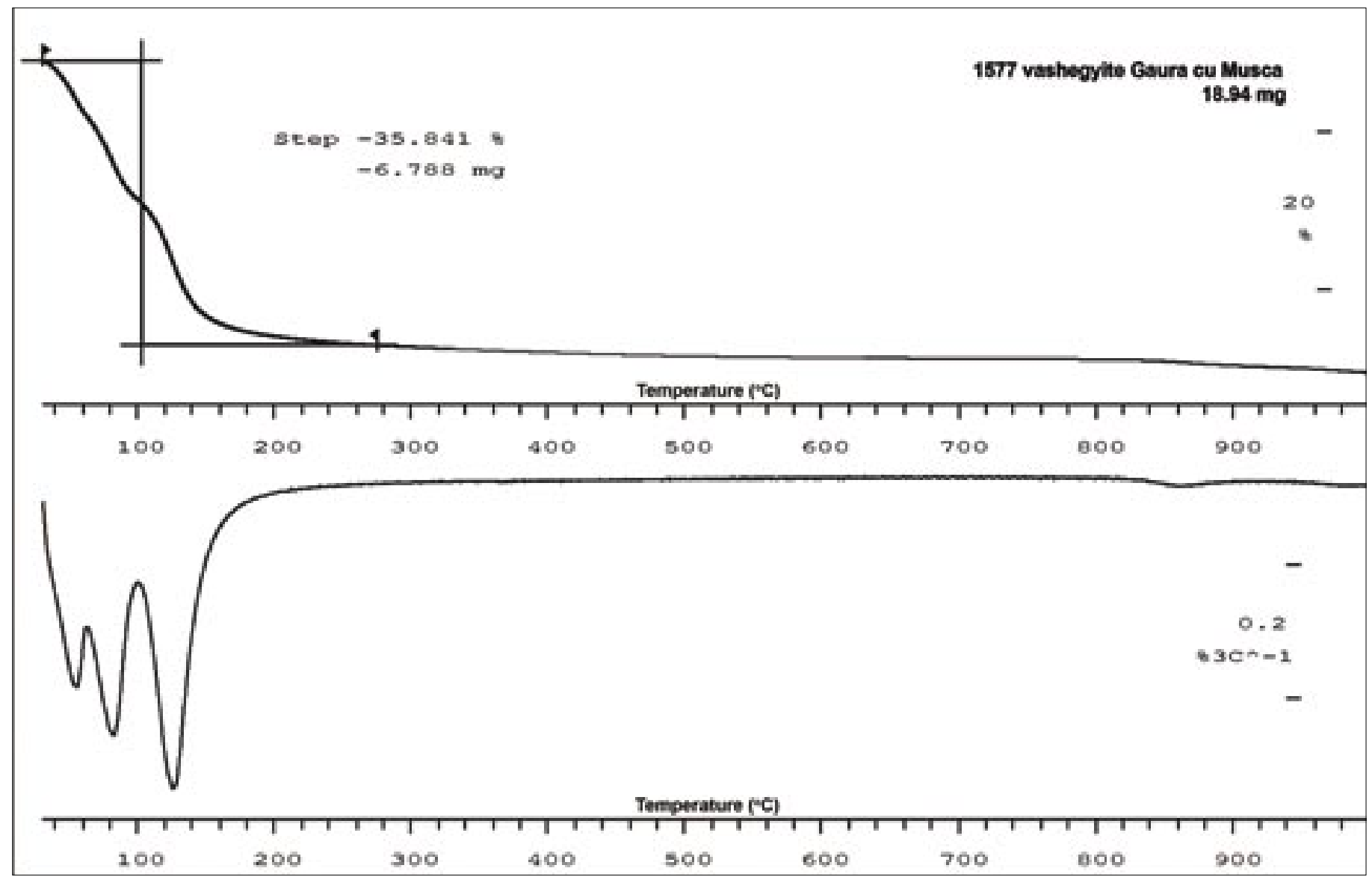

Fig. 4. TG and DTG curves of vashegyite. 


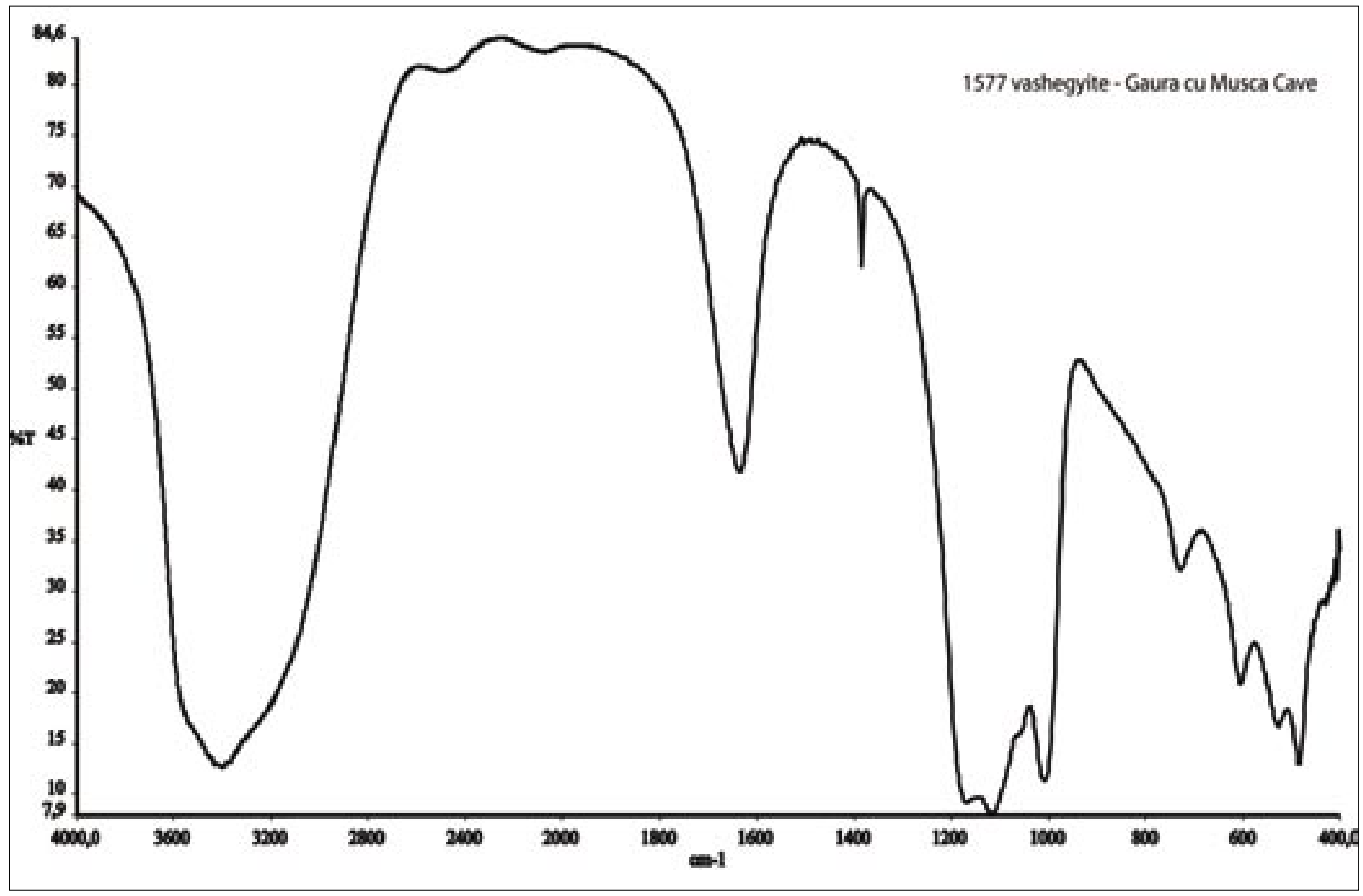

Fig. 5. FT-IR spectrum of vashegyite.

reflections using the nonlinear least-square program of Holland \& Redfern (1997) gave $a=10.766(2) \AA, b$ $=15.00(4) \AA, c=22.661(1) \AA, \mathrm{V}=3660.62 \AA^{3},(Z=4)$. A fully indexed powder-diffraction pattern is given in Table 1. As a general observation, the measured Xray powder data are very close to those obtained for the vashegyite from Chvaletice (Johan et al., 1983).

The thermal analysis of vashegyite was performed on $18.94 \mathrm{mg}$ of the sample using a Mettler Toledo apparatus. The temperature ranged from 30 to $1000^{\circ} \mathrm{C}$, under a constant flow of nitrogen $(100 \mathrm{~mL} / \mathrm{min})$ and a heating rate of $5^{\circ} \mathrm{C} / \mathrm{min}$. The thermogravimetric (TG) and differential thermogravimetric (DTG) plots of vashegyite powders are shown in Fig. 4. The DTG curve shows a triple step dehydration process. Examining the TG curve, it is evident that the water expulsion begins as soon as the temperature rises. The small endothermic effect recorded at $58^{\circ} \mathrm{C}$ on the DTG curve accounts for the release of residual water adsorbed on the powder surface. The major weight loss $(35.9 \%)$ is located between 80 and $150^{\circ} \mathrm{C}$. The marked endothermic effect with a maximum at $128^{\circ} \mathrm{C}$ indicates that the removal of the remaining molecular water was completed. In the temperature range $\sim 800$ to $1000^{\circ} \mathrm{C}$, a weight loss of ca. $1 \%$ can be detected on the TG curve. This is reflected on the DTG curve by a broad, weak endothermic effect by the maximum at $860^{\circ} \mathrm{C}$. A similar effect (at $883.5^{\circ} \mathrm{C}$ ) was observed by Forti et al. (2000) when investigating the vashegyite from Shpella e Zezë Cave in Albania.

The similarity of the thermal behaviour of our sample with those from Chvaletice and the Albanian cave was observed. Although Johan et al. (1983) discuss only two endothermic effects, their DTG spectrum (Fig. 2E, page 493) shows three peaks similar to ours. The only difference is that our peaks are slightly shifted towards lower temperatures. Furthermore, all three thermal analyses (Johan et al., 1983; Forti et al., 2000, and the present study) identified between temperature range of 800 and $860^{\circ} \mathrm{C}$ an endothermic effect that probably is due to the expulsion of $\mathrm{OH}$ groups.

\section{Chemical composition}

Chemical analyses of vashegyite were carried out with a sequential Jobin-Yvon ULTIMA ICP-AES at the Institut des Sciences de la Terre d'Orleans (France). The detection limits for the analysed elements are less than 0.005 wt. $\%$.

The chemical composition of vashegyite (mean value of five analyses, expressed as wt.\%) is $\mathrm{P}_{2} \mathrm{O}_{5}=29.71$, $\mathrm{Al}_{2} \mathrm{O}_{3}=26.52, \mathrm{Fe}_{2} \mathrm{O}_{3}=0.23, \mathrm{SiO}_{2}=0.16, \mathrm{CaO}=0.05$, $\mathrm{MgO}=0.17, \mathrm{Na}_{2} \mathrm{O}=0.15$, and $\mathrm{H}_{2} \mathrm{O}=42.94$; total 99.93. Water was determined by loss of ignition, but then recalculated for charge balance of the chemical formula. The empirical formula calculated on the basis of $20(\mathrm{Al}+\mathrm{P}+\mathrm{Fe})$ is $\left(\mathrm{Al}_{10.91} \mathrm{Fe}^{3+}{ }_{0.06} \mathrm{Na}_{0.1} \mathrm{Ca}_{0.02}\right.$ $\left.\mathrm{Mg}_{0.08}\right)_{\Sigma=11.17}\left[\left(\mathrm{PO}_{4}\right)_{8.78}\left(\mathrm{SiO}_{4}\right)_{0.056}\right]_{\Sigma=8.83}(\mathrm{OH})_{6.17} \cdot 43.79 \mathrm{H}_{2} \mathrm{O}$.

The positions of the $\mathrm{X}$ atoms (centre of the tetrahedral group) are statistically occupied by $\mathrm{P}$ and $\mathrm{Si}$ atoms with a ratio of 8.78:0.056, which means that the $\mathrm{P}$ to Si substitution has no significance. 


\begin{tabular}{|c|c|c|c|c|c|c|c|}
\hline \multirow[t]{2}{*}{$\mathrm{Nr}}$. & \multicolumn{4}{|c|}{$\begin{array}{l}\text { Vashegyite } \\
\text { (this study) }\end{array}$} & \multicolumn{3}{|c|}{$\begin{array}{l}\text { Vashegyite } \\
\text { Chvaletice }^{*}\end{array}$} \\
\hline & $d_{\text {meas. }}(\AA)$ & $d_{\text {calc. }}(\AA)$ & I & $\mathrm{hkl}$ & $d_{\text {meas }}(\AA)$ & $d_{\text {calc. }}(\AA)$ & I \\
\hline 1 & 11.182 & 11.330 & 10 & 002 & 11.300 & 11.34 & 10 \\
\hline 2 & 7.525 & 7.501 & 7 & 020 & 7.500 & 7.486 & 8 \\
\hline 3 & 6.899 & 6.924 & 3 & 112 & 6.900 & 6.919 & 3 \\
\hline 4 & 6.240 & 6.255 & 8 & 022 & 6.260 & 6.247 & 7 \\
\hline 5 & 5.592 & 5.665 & 1 & 004 & 5.620 & 5.377 & 1 \\
\hline 6 & 5.402 & 5.383 & 2 & 200 & 5.385 & 5.377 & 4 \\
\hline 7 & 4.299 & 4.373 & 1 & 220 & 4.351 & 4.367 & 1 \\
\hline 8 & 3.726 & 3.750 & 2 & 040 & 3.745 & 3.743 & 4 \\
\hline 9 & 3.461 & 3.462 & 2 & 224 & 3.460 & 3.459 & 3 \\
\hline 10 & 3.297 & 3.335 & 4 & 312 & 3.297 & 3.332 & 6 \\
\hline 11 & 3.132 & 3.168 & 2 & 313 & 3.169 & 3.166 & 1 \\
\hline 12 & 2.902 & 2.891 & 8 & 330 & 2.912 & 2.911 & 9 \\
\hline 13 & 2.852 & 2.832 & 2 & 331 & 2.884 & 2.888 & 2 \\
\hline 14 & - & - & - & 008 & 2.834 & 2.834 & 4 \\
\hline 15 & 2.699 & 2.691 & 2 & 400 & 2.687 & 2.688 & 3 \\
\hline 16 & 2.625 & 2.618 & 1 & 402 & 2.611 & 2.616 & 2 \\
\hline 17 & 2.544 & 2.533 & 1 & 420 & 2.533 & 2.530 & 3 \\
\hline 18 & 2.447 & 2.441 & 3 & 062 & 2.443 & 2.437 & 4 \\
\hline 19 & 2.285 & 2.287 & 3 & 064 & 2.280 & 2.284 & 4 \\
\hline 20 & 2.194 & 2.186 & 2 & 440 & 2.183 & 2.183 & 2 \\
\hline 21 & 2.139 & 2.131 & 2 & 510 & 2.136 & 2.129 & 2 \\
\hline 22 & 2.042 & 2.051 & 2 & 513 & 2.045 & 2.049 & 2 \\
\hline
\end{tabular}

Table 1. X-ray powder diffraction data for vashegyite from Gaura cu Musca Cave and Chvaletice.

\section{Vibrational spectra}

Fourier-transform infrared spectra were recorded from 4000 to $400 \mathrm{~cm}^{-1}$ using a Perkin-Elmer $1760 \mathrm{X}$ FT-IR spectrometer with 64 scans and a resolution of $2 \mathrm{~cm}^{-1}$. Samples were prepared as $\mathrm{KBr}$ pellets with diameters of $13 \mathrm{~mm}$. The FT-IR spectrum of the dull white vashegyite (Fig. 5) presents sharp and welldefined absorption bands that are comparable in position and relative intensity to bands in the spectra of the Chvaletice specimen (Johan et al., 1983) and other Al-phosphates (Ross, 1974; Socrates, 2001). A list with all the bands and their tentative assignment is tabulated in Table 2 .

\section{CONCLUSIONS}

The analytical investigations presented above confirm the presence of vashegyite, a rather rare, orthorhombic, highly hydrated Al-phosphate in the Gaura cu Muscă Cave. The mineral has a tabular to flaky habit and perfect cleavage on (001), which indicates a sheet structure.

Results show that the chemical composition of vashegyite significantly varies from one sample to another (i.e., the amount of $\mathrm{Al}$ and P). Furthermore, some of the vashegyite samples we analyzed showed $\mathrm{SiO}_{2}$ as high as $6 \mathrm{wt} . \%$. The largest differences in the content of $\mathrm{SiO}_{2}$ are found in those samples collected

\begin{tabular}{|l|c|}
\hline Frequency $\left(\mathrm{cm}^{-1}\right)$ & Assignment \\
\hline 3400 & OH stretching \\
\hline 3200 & OH stretching \\
\hline 1635 & H-O-H bending \\
\hline 1384 & O O-H bending d \\
\hline 1165 & O-P-O stretching \\
\hline 1115 & O-P-O stretching \\
\hline 1007 & O-P-O stretching \\
\hline 729 & Al-OH ${ }_{2}$ or OH bending \\
\hline 604 & O-P-O bending \\
\hline 525 & $\begin{array}{l}\text { O-P-O bending } \\
\text { O-P-O bending }\end{array}$ \\
\hline 482 & O-P-O bending \\
\hline
\end{tabular}

Table 2. Position and assignments of the FT-IR absorption bands of vashegyite. 
within the silty horizon. Values between 3 and 7 wt.\% have also been reported by Kashima (1988) from various caves in Japan.

The sequence of events producing the three phosphate minerals identified in the Bats Room is as follows: the precipitation of vashegyite is the result of the reaction between fresh guano P-rich solutions and aluminium derived from interbedded clay horizon. Its deposition takes place in slightly acidic conditions and under a perennially damp environment. In the lower part of the sequence, within the old guano layer, drier but still acidic conditions favoured the precipitation of ardealite. As the $\mathrm{pH}$ of the environment buffers near the limestone bedrock, slightly alkaline conditions allowed the deposition of crandallite.

\section{ACKNOWLEDGEMENTS}

The authors thank M. Chirienco and S. Constantin for field assistance, Dr. H. Effenberger for comments on the vashegyite chemistry, and D. Keravis for ICPAES analyses. The thorough reviews of C. Hill, P. Forti, and F. Frau are gratefully acknowledged. This study was supported by the Romanian CNCSIS grant 53/1696 to BPO.

\section{REFERENCES}

Atencio D., Coutinho J.M.V. \& Menezes Filho L.A.D., 2005 - Roscherite-group minerals from Brazil. Axis, 1: $1-18$.

Bannister F.A. \& Hutchinson G.E., 1947 - The identity of minervite and palmerite with taranakite. Mineral. Mag., 28: 31-35.

Barczuk A. \& Tatur A., 2003 - Biogenic phosphate and sulphate minerals in the soils of Antarctic Peninsula. Zeszyt, 23: 41-43.

Clinton H.G., 1929 - Vashegyite and barrandite in Nevada. Am. Mineral., 14 (11): 434-436.

Forti P., Galli E. \& Rossi A., 2000 - Mineraligeneticamente correlati al guano in una grotta naturale dell'Albania. Primo contributo. Le Grotte d'Italia, V (1): 45-59.

Frondel C., Ito J. \& Montgomery A., 1968 - Scandium content of some aluminum phosphates. Am. Mineral., 53: $1223-1231$.

Hausen D.M., 1962 - Schoderite, a new phosphovanadate mineral from Nevada. The American Mineralogist, 47: 637-650.

Hill C.A. \& Forti, P., 1997 - Cave minerals of the world ( $2^{\text {nd }}$ ed.). National Speleological Society, Huntsville, $464 \mathrm{p}$.
Holland T.J.B. \& Redfern S.A.T., 1997 - UNITCELL: a non-linear least-squares program for cell-parameter refinement implementing regression and deletion diagnostics. J. Appl. Crystal., 30: 84.

Johan Z., Slansky E. \& Povondra P., 1983 - Vashegyite, a sheet aluminum phosphate: new data. Can. Mineral., 21: 489-498.

Kashima N., 1988 - Geochemistry of the spelean and insular phosphates from Japan: variscite and vashegyite. J. Speleol. Soc. Japan, 13: 18-28.

Kashima N., 1993 - Speleominerals of Japanese Islands. Beijing: Proc. $11^{\text {th }}$ Int. Congr. Speleol., 76-77.

Kizaki H., 1983 - New cave minerals, vashegyite and koninkite from Oni-ana Cave. Japan Caving, 14: 2830 (in Japanese).

Koch S. \& Sarudi I., 1963 - The hydrous basic aluminum phosphates of Zeleznic (Vashegy), Slovakia (CSSR). Acta Mineral. Petrogr., Szeged, 16: 3-10.

McConnell D., 1974 - Are vashegyite and kingite hydrous aluminium phyllosilicates with kaolinite-type structure? Mineral. Mag., 39: 802-806.

Milton C., Dwornik E.J. \& Marinenko J.W., 1982 Vashegyite from Nevada and "palfevite" (= richmondite) from Nevada and from Arkansas (= kingite). In: McFarland J.D. III \& Bush W.V. (Eds.) - Contributions to the geology of Arkansas, I, Arkansas Geological Commission Miscellaneous Publication, 18: 53-62.

Negrea A. \& Negrea S., 1979 - Pesterile din Defileul Dunarii si fauna terestra. In: Orghidan T. \& Negrea S. (Eds.) - Speologia, Bucuresti: Editura Academiei RSR: 30-75.

Ross S.D., 1974 - Phosphates and other oxy-anions of group V. In: Farmer V.C. (Ed.) - The infrared spectra of minerals. London: Mineralogical Society, Monograph 4: 383-422.

Rüger F., Senf L. \& Witzke T., 1995 - Die Saalfelder Feengrotten: Seltene Sekundärmineralien aus Thüringen. Lapis, 20 (1): 15-26.

Socrates, G., 2001, Infrared and Raman characteristic group frequencies. Tables and charts. Chichester: John Wiley \& Sons, Ltd., $3^{\text {rd }}$ ed.: 283-327.

van Tassel R., 1985 - Mineraux phosphates secondaires (vashegyite, destinezite, wavellite, crandallite, phosphate de fer) a Haut-le-Wastia, Province de Namur (Belgique). Bull. Soc. Belge Géol., 94: 19-27.

Vennum W., Dunning J., Leu R., Andersen B. \& Bergk K., 1994 - Unusual phosphate minerals and diatombearing stalactites from the Farallon Islands. Calif. Geol., 47 (3): 76-83.

Zimanyi K., 1909 - Vashegyite, ein neues basisches Aluminiumphosphat vom Comitat Gömör. Z. Krist., 47: 53-55. 